\title{
Impact of Digital Technology on Preschoolers : A Review
}

\author{
Seema Yadav, Prof. Charu Vyas
}

Department of Home Science, Banasthali University, Newai, Rajasthan, India

\begin{abstract}
Article Info

Volume 8, Issue 2

Page Number : 223-227

Publication Issue

March-April-2021

\section{Article History}

Accepted : 16 March 2021

This paper shows how the advent of digital technologies is driving a reconceptualization of the underlying assumptions of innovation policy. There is conclusive evidence that digital equipment, tools and resources can, where effectively used, raise the speed and depth of learning for preschoolers. There is indicative evidence that the same can be said for some aspects of literacy, especially writing and comprehension. Digital technologies and electronic media devices appear to be appropriate means to improve basic literacy and social skills, especially in primary settings. The level of impact is generally similar to other changes to pedagogies which are effective in raising attainment although the use of digital learning has other benefits. Additionally, the extent of the effect may be influenced by the level of capability of teachers to use digital learning tools and resources effectively to achieve improved learning outcomes.
\end{abstract}

Published : 22 March 2021
Keywords : Aquatic Angiosperms, Heranj Pond, Wetland, Ecosystems.

\section{INTRODUCTION}

The rapid expansion of technology into the worlds of young people has created a new generation which can use computers, mobile devices and other digital technologies as easy as winking. Nevertheless, in the context of early childhood settings there are some influences that may differentiate the technology use behaviors of preschool children which are generally constructed at home or school environment.

Technology use is becoming increasingly prominent in both K-12 settings and the workplace. Early childhood education is often a time for preparing students with the basic skills they need for K-12 education, so digital literacy may be another area in which early childhood education could help prepare young children. When we talk about technology in education, we mean the tools or machine in the classrooms. Like computers, tablets, printers and music system and all. In preschool classroom technology can take many forms. Young children enjoy to listening songs, books and stories. When a teacher is not available to read with a student, they can listen on a digital player, like compact disk player or electronic device such as iPod. 
Still, not everyone agrees that technology should be in early childhood education. Debates about the role of technology in early childhood education are ongoing, with some providers, parents, and others yet to be convinced about the potential benefits of technology.

Nowadays, children are fascinated to play with technology and electronic media devices like smart phones, internet connected TVs, video games, high speed internet etc. Children have propensity to be more active consumer of technology and many electronic digital products are intend to the youth market. This is also very true that parents \& youngsters use devices and gadgets to keep their children quiet busy and engaged for a long period of time so that they can be free and do their work.

According to Julie Lewis, The researchers are clear that if children spend too much time watching electronic screens in their early age then the adverse effect can be seen. Parents should know about correct and appropriate use of media technology which is useful for their children as well as the time limit related to screen timings spend by child on daily basis.

Interior Health suggests a time limit according to the age range, regarding how much time children should be using technology

\section{$>\quad$ from 0 to two years of age: (None) \\ $>\quad$ Children from three to five years of age: (1 hour per day) \\ $>$ Children from six to twelve years of age: ( 2 hours per day)}

If we see the teaching approach or teaching styles, it is very true that there is a unorganized connection between what is taught and what actually happens in the outside world or real world or society, so in order to catch up with the real world to the schools and early childhood centers they need to incorporate with advanced technology in their curriculum. Since media devices are taking used in life style, it is very important to include or integrate technology into learning environment. The quality of experiences encountered by young children during this period has immense and vast impacts on their personal growth and development and also their learning abilities.

\section{REVIEWS}

Alper T. Kumtepe (2006) investigates the effect of use of computer on children's social skills in kindergarten. The total sample included 12,929 children. Results indicate that children, use computers more competently and masterly, show better effective social skills and less behavioral problem, rated by their teachers.

Teresa Ann Shanahan-Braun (2009) this study was done to know how useful and advantageous computers are related to overall development like, language development, cognitive development, and social development with preschoolers. Result showed that as compared to traditional preschool activities, computers have not been proven to be more beneficial for the typical developing child. However, technology is here to stay and preschool children who do not have access to computers need to be prepared to use technology by the time they enter into preschools.

H. Fierman et al (2010) aim of this study to know the relationship between media exposure in infancy and developmental outcomes in children from families with low socioeconomic status in the United States. Result show strong and powerful evidence in support of no media exposure or screen time needed to age 2 years, although further research is needed.

Lorna Savage (2011) aim of this study was to gives factual information to explore 3 to 5 year old children's social interactions on media or technologyrich local authority of preschools by: identifying the observable child interactions as children busy with media or technology in preschools. The study adopts an inclusive definition of technology and gives a broad range of resources, providing new concepts related to the role of digital technologies in social 
interaction and education. And the all round development of children.

Joseph Juzwiak (2012) discusses that use e-Books as a means of technology integration in classrooms, and in the area of emergent literacy. In this study researcher focused on answering the research question: "How does e-Books support emergent reader's literacy development"? This study also and looks at the effect of reading e-Books on students "motivation to read".

Ruth Nancy Zomer, (2014) the research show the effect of technology use on learning, educating and engagement for children age range from 3 to 6 in early childhood educational settings. Thirty peerreviewed articles, selected from an extensive search of the literature, are organized and discussed by topic: literacy, numeracy, social interactions and engagement. Methodological concerns include sample sizes, reliability and validity of data collection tools, lack of control groups, pedagogy and basic design issues. Key findings specify that $94 \%$ of results describe in the studies show a positive influence of technology use. A disproportionate number of studies focus on literacy.

Fathi Ihmeideh (2015) purpose of the study to investigate the effect of e- book on enhancing preschool children's emergent literacy, in comparison to children who were exposed to regular printed books. Both experimental and control group were taken for this study. Total 92 children were selected for pre test and post test on print awareness, alphabetic knowledge, and vocabulary to know the effectiveness of e- book. The result indicates children in experimental group performed better then control group and significant differences were found on the based of gender, as the female children show superior skill on emergent literacy to the male children. On the basis of this result it's recommended that preschool centers should include or integrate e- book activities into their classrooms.

Nancy R. Zomer \& Robin H. Kay (2016) this study provides literature review of students who use technology in early childhood education. 30 peer- reviewed articles from 11 countries, selected from a comprehensive search of the literature. Methodological concerns included limited sample sizes and descriptions, and the limited number of technology tools used. Fewer studies show that technology and media had a positive impact on engagement, and mathematics skills, social interactions. So many studies also show that technology had a positive impact on sequencing, to develop visual perception, creative thinking, and fine motor capability.

Ciera Brianna Mills, Lexington et al (2016) this study analyze the efficacy of digital media on emergent literacy skills, specially alphabet knowledge, print awareness, and phonological awareness, on children birth to four year. A systematic search on literature review identified. Results show useful and positive effects of digital media on emergent literacy skills. A checklist was prepared to guide clinicians, parents, and others for correct use of screen media.

Hyong Yoon Chang et al (2017) aim of this study was to explore the exposure of smart digital devices among 2-5 years of children from Korea. 400 parents of 2-5 year old children were the sample of this study. Demographic data information and the frequency of media use, time of media use, age at first use of media was self-reported. This study gives detailed information and comprehensive facts on children's contemporary and present time use of media access.

Katie A. Pacigathis (2017) research report synthesizes the research work, and practices that involved technology and media for young children. A combination of snowball sampling, systematic database searches, reverse searches, and hand searches are used. Results show that there were fewer examples from research and practice related to infants and toddlers than other age groups. Result show that children's interactions with digital media and technology are encouraging the overall development of children.

Cristina E. Kuta (2017) discusses the effects of excessive screen time on language development for 
children under 6 years and analyzes interventions to reduce screen time. Toolkit was created. Being consistent about providing a few minutes of screen time education at every wellness visit from 2-monthsold to 5 years-old sets a solid foundation for parents and children to create healthy screen time habits at home.

Michelle M. Neumann (2017) this study was a current discovery on using touch screen mobiles and tablets in reinforcing the development of early year literacy within a conceptual framework. Findings show that tablets have the latent qualities to strengthen children's emergent literacy skills. although, the optimum use of tablets for early literacy learning mighty be based upon the type of scaffolding used by teacher or parent and the availability and best quality of literacy tablet applications. Practical association, implications and suggestions for further future researches are discussed.

Aitchison, Emily (2018) this study the researcher investigate that how technology could be put into practices in early childhood education and he also demonstrate that how it works on children. The data were collected from using case study method which involved children from 3-5 year. The result showed that including technology in education is far easier than many practitioners expect, and it need to be flexible, fun and relevant to the children, so that the young children can have exposure, learning experiences and sense of self control.

Himanshu Rastogi (2019) the paper is based on secondary source of information gathered from various authentic websites, research papers, newspapers and magazine articles. The result show that education is transforming with rapid pace from being traditional chalk and talk based and book based study to internet based education system. The traditional class rooms with black boards are being replaced by smart classes fitted with audio and visual system.

Sezan Sezgin et al (2021) this study seeks to define the possible influences; effects and praxis of technology use in early childhood settings, and also intend to explore the current research trends about technology use in the field of early childhood education. Data were gathered from several scientific databases. Review of the articles and scientific documents were conducted in two rounds. Review process was repeated by two researchers different from the first round, and a different set of two researchers were cross checked in the second round. This study also draws on a discussion about pedagogical effects of technology use in early childhood settings.

\section{CONCLUSION}

Our review of digital technology suggested that early childhood literacy affected successfully, technology is on very top and play a major and significant role in supporting and reinforcing the early year literacy. Now a day's children have opportunity to explore with different electronic devices like touch screens loaded with variety of interactive media experiences with proper well designed search engine etc.

Electronic devices can be very useful but at the same time we have to know that it can be very dangerous for children because it has negative impact also if they are excessive over-used.

The review based findings showed that this is important and crucial to be aware about the effective and right use of mobile phone and digital technology should different across both informal and formal settings and also how technology can be used as additional material for classroom settings for both inside and outside and early childhood curriculum, so further more researches, exploration and effective work is required to know and to understand that how to adapt the environment of early years to meet the variety of optimal needs of young children and their families. 


\section{REFERENCES}

\section{Journals}

[1]. Amelia, K.Moody (2010). Using electronic book in the classroom to enhance emergent literacy skill in young children. Journal of literacy and technology, 11(4).

\section{Webliography}

[2]. https://literacytrust.org.uk/researchservices/research-reports/how-digitaltechnology-can-support-early-language-andliteracy-outcomes-early-years-settings-reviewliterature/

[3]. https://www.researchgate.net/publication/2719 39339_Children_under_five_and_digital_techn ologies_implications_for_early_years_pedagogy

[4]. https://www.researchgate.net/publication/3187 03778_TECHNOLOGY_USE_IN_PRESCHOOL _EDUCATION_A_SYSTEMATIC_MAPPING_ STUDY

[5]. https://study.com/academy/lesson/technologyin-the-preschool-classroom.html

[6]. https://study.com/academy/lesson/technologyin-the-preschool-classroom.html

[7]. https://study.com/academy/lesson/technologyin-the-preschool-classroom.html

[8]. https://www.semanticscholar.org/paper/THEEFFECTS-OF-COMPUTERS-ONKINDERGARTEN-CHILDREN-\%E2\%80\%99Kumtepe/61b94ca978fd81148bd527948bad0d7b $6 \mathrm{c} 4073 \mathrm{fc}$

[9]. https://www.ncbi.nlm.nih.gov/pmc/articles/PM C4046626/

[10]. https://dspace.stir.ac.uk/bitstream/1893/1934/1/ Plowman\%20et\%20al\%20supporting\%20learni ng\%20Research\%20Papers\%20in\%20Education .pdf

[11]. https://englishagenda.britishcouncil.org/contin uing-professional-development/teachereducator-framework/demonstrating-effectiveteaching-behaviour/teaching-and-technologycase-studies-india
[12]. https://www.theseus.fi/handle/10024/142769

[13]. https://link.springer.com/article/10.1007/s10643 $-013-0608-3$

\section{Cite this article as :}

Seema Yadav, Prof. Charu Vyas, "Impact of Digital Technology on Preschoolers : A Review", International Journal of Scientific Research in Science and Technology (IJSRST), Online ISSN : 2395-602X, Print ISSN : 2395-6011, Volume 8 Issue 2, pp. 223-227, March-April 2021. Available at doi : https://doi.org/10.32628/IJSRST218232 Journal URL : https://ijsrst.com/IJSRST218232 